\section{The Relationship Between the Intellectual Capital Disclosure and Cost of Debt Capital - A Case of Slovenian Private Audited Organisations}

\author{
Neca Stropnik \\ University of Maribor, Faculty of Economics and Business, Slovenia \\ neca.stropnik@um.si \\ Bojana Korošec \\ University of Maribor, Faculty of Economics and Business, Slovenia \\ bojana.korosec@guest.um.si

\section{Polona Tominc} \\ University of Maribor, Faculty of Economics and Business, Slovenia \\ polona.tominc@um.si
}

\begin{abstract}
The existing empirical research into the association between intellectual capital disclosures by organisations and the cost of debt is scarce or is based solely on the samples of the (large) listed organisations. Since agency issues between management/owners and lenders exist also in (large) private organisations whose financing is greatly dependent on loans and whose audited annual reports can be a source of additional information for external users, we performed an empirical research to find the answer to the question whether the level of intellectual capital disclosure (as a whole and of its sub-categories) of organisations is associated with the cost of their debt capital. Our study was performed on a sample of private Slovenian organisations with audited annual reports. The results of our research did not reveal that lenders would take into account intellectual capital disclosures by Slovenian private audited organisations as the information about the potential for their future cash flows when deciding on the cost of debt issued to these organisations.
\end{abstract}

Key words: intellectual capital, intellectual capital disclosure, intellectual capital disclosure level, cost of debt, private organisations, content analysis

\section{Introduction}

In modern economic environment, intellectual capital is understood as "a non-monetary asset without physical substance but [which] possesses value or [which] can generate future benefits” (Choong, 2008, p. 613). It is usually
ORIGINAL SCIENTIFIC PAPER

RECEIVED: DECEMBER 2016

REVISED: NOVEMBER 2017

ACCEPTED: NOVEMBER 2017

DOI: 10.1515/ngoe-2017-0019

UDK:005.336.4:159.953/.955:33.067

JEL: M41, M49

Citation: Stropnik, N., Korošec, B., \& Tominc, P. (2017). The Relationship Between the Intellectual Capital Disclosure and Cost of Debt Capital A Case of Slovenian Private Audited Organisations. Naše gospodarstvo/Our Economy, 63(4), 3-16. DOI: 10.1515/ ngoe-2017-0019

\section{NG \\ OE}

NAŠE GOSPODARSTVO OUR ECONOMY

Vol. 63 No.4 2017

pp. $3-16$ 
classified into three sub-categories, i.e. human, structural and relational capital ${ }^{1}$ (e.g. Edvinsson, 1997; Sveiby, 1997; Bontis, 1998; Guthrie, 2001; MERITUM, 2002; April et al., 2003; Li et al., 2008; Cronje \& Moolman, 2013; Sanchez et al., 2013). It is also considered as one of the main value creators in the process of value creation in organisations and in the new economy (MERITUM, 2002; OECD, 1996, 2007). Since accounting theory recognises intellectual capital in a very limited extent and since a balance sheet reports only those intangible assets that fulfil the required criteria (e.g. ownership rights, goodwill), it is necessary to report or obtain more comprehensive (non-financial, forward-looking) information about it/them somewhere else. It has been shown that disclosures significantly supplement companies' financial statements or are, as stated by Zéghal and Maaloul (2011), “considered as a solution to the negative consequences of non-recognition of intangibles in financial statements." Intellectual capital disclosures are almost exclusively voluntary; they can be given separately or within some other (public) reporting (e.g. business reports, annual reports, IPO prospectuses) and are meant both for external and for internal users. The latter need them mainly for the purpose of managing this capital as effectively as possible (i.e. as a management tool), whereas the former (e.g. potential investors, business partners and lenders) need such disclosures to determine the potential and the value of an organisation (i.e. as a communication tool).

Empirical research into the economic consequences of intellectual capital reporting is numerous and mainly based on the assumption that additional disclosures usually lead to the reduction of information asymmetry and to the lessening of the uncertainty regarding the predictions of future operations (and future cash flows) of organisations ${ }^{2}$ (e.g. Orens et al., 2009; Boujelbene \& Affes, 2013; Mangena et al., 2010, 2016). For that reason, a number of studies focused on the importance of such disclosures for owners (e.g. Abdolmohammadi, 2005; Orens et al., 2009; Bou-

\footnotetext{
1 The classification of a large number of intellectual capital items into different sub-categories adequately supplements its definition (Choong, 2008, p. 617). Human capital thus comprises skills and knowledge of employees and can be studied at individual level (e.g. personal attributes, technical competence and creativity) or at organisation level (e.g. team work, healthy work environment). Structural capital is knowledge that cannot be separated from the organisations (e.g. organisational structures, procedures, systems, databases, patents) and relational capital is the relationship between the organisation and its external stakeholders (e.g. customers, resource providers, banks and shareholders) (Joshi et al., 2013, p. 267).

2 The Organisation for Economic Co-operation and Development (OECD, 2007, p. 6) goes a step further by stating that organisations should "provide financial markets with sufficient and relevant non-financial information about intellectual assets, thereby improving the exercise of ownership rights and tightening the financial discipline of management and boards, with positive economic consequences."
}

jelbene \& Affes, 2013; Taliyang et al., 2014; Mangena et al., 2010, 2016), whereas only a few studies addressed this issue from the perspective on lenders and/or in relation to the cost of debt capital (Orens et al., 2009; Hsuehchang, 2013). Considering the significance of agency issues and public availability of information about intellectual capital (Williams, 2001; Bozzolan et al., 2003; Abdolmohammadi, 2005; Abeysekera, 2006), the research into the associations between intellectual capital disclosures and the cost of debt capital (Orens et al., 2009; Hsuehchang, 2013) has focused on listed organisations. Although there may exist the agency issue regarding private (non-listed) organisations with lenders as the main source of external financing (Koren et al., 2014), we have not been able to find empirical research on the associations between intellectual capital disclosures of such private organisations and the cost of their debt. However, a few studies addressed the cost of debt for private organisations (Fortin \& Pittman, 2007; Karjalainen, 2011; Kim et al., 2011; Minnis, 2011). As regards Slovenia, the research by Koren et al. (2014) dealt with Slovenian private organisations, but its focus was on the (voluntary) auditing. In addition, we found only three studies that measured the extent of intellectual capital disclosures in the annual reports of Slovenian organisations (Rodman, 2005; Jelenovec, 2015; Stropnik \& Korošec, 2016).

Based on the fact (1) that the association between intellectual capital disclosures and the cost of debt capital has been proven for listed organisations (Orens et al., 2009; Hsuehchang, 2013), (2) that larger private organisations may also face agency issues between management/owners and lenders (Kosi \& Valentincic, 2013), that (3) organisations that depend on external financing are likely to undertake an expended disclosure policy (Francis et al., 2005), and that "creditors of private firms will likely make use of all publicly available information” (Peek et al., 2010, p. 54), so private organisations may use annual reports as an important communication channel for additional/intellectual capital information, and given that (4) the information about intellectual capital of private organisations is publicly available in their audited annual reports, and considering (5) the importance of debt/loans financing in bank-based economies (as is Slovenian economy ${ }^{3}$ ), and taking into account (6) the credit crunch $^{4}$ economic situation in the years 2013 and 2014 in Slovenia, a research question whether intellectual capital disclosures of private audited organisations are associated with the cost of debt capital, i.e. whether they are associated with the bank's decisions when granting loans, arises.

\footnotetext{
3 Slovenian economy is a bank-based economy due to the prevalence of monetary financial institutions (Banka Slovenije, 2014).

4 Sengupta (1998, p. 473) argues that "there is greater reliance on disclosures when the market uncertainty surrounding the firm is high".
} 


\section{Literature Review and Hypothesis Development}

The information about or the disclosure of intellectual capital has become a major object of research ${ }^{5}$. It can be broadly classified into (1) the research on factors which have an impact on intellectual capital disclosures (e.g. size of the organisation and industry type (Brüggen et al., 2009; Whiting \& Woodcock, 2011), firm age (White et al., 2007; Sonnier et al., 2009), corporate governance (Li et al., 2008; Hidalgo et al., 2011; Haji \& Ghazali, 2013), listing status (Williams, 2001)), and (2) the research which assesses the impact of intellectual capital disclosures on different areas of organisation's performance and its valuation. The latter research provides evidence on, for example, significant and positive effect of intellectual capital disclosures on market capitalization and firm value (Abdolmohammadi, 2005; Orens et al., 2009), the impact of intellectual capital disclosures on the reduction of information asymmetry (Orens et al., 2009; An et al., 2011) and (consequently) the impact of voluntary intellectual capital disclosures on the reduction of the cost of equity capital (Orens et al., 2009; Boujelbene \& Affes, 2013; Mangena et al., 2010, 2016). In these studies, the hypotheses were tested on the samples of (large) organisations, which are listed on the stock exchanges of developed capital markets, e.g. the USA (Abdolmohammadi, 2005), the United Kingdom (Mangena et al., 2010, 2016), France (Boujelbene \& Affes, 2013) and other individual countries of continental Europe (Orens et al., 2009). These are thus the studies whose very focus of research (i.e. the impact of intellectual capital disclosure on market capitalization and market value of organisations, the information asymmetry and the cost of equity financing) requires such samples, i.e. listed organisations, which are bound to more extensive disclosure due to their ownership and size ${ }^{6}$. These organisations also have important influence on equity markets (Cairns et al., 2011). It can, therefore, be expected that these organisations will (voluntarily) disclose more information regarding their intellectual capital in comparison with private organisations ${ }^{7}$. Because of a relatively strong direct correspondence between the management and the owners, or between management/ owners and lenders, the latter organisations usually do not

\footnotetext{
5 The research about intellectual capital is very active one and the vast body of research was categorised by Branswijck and Everaert (2012) into (1) theoretical research concerning the definition of intellectual capital, (2) the research focusing on managing intellectual capital, and (3) the research on intellectual capital disclosures.

6 As regards Slovenia, such organisations come under the Slovenian Companies Act (ZGD-1), the Slovenian Financial Instruments Market Act (ZTFI) and the EU Directive 2014/95/EU.

7 Private organisations are organisations that are not traded publicly on stock exchanges.
}

disclose additional information about the organisation and its operations/intellectual capital publicly or they present them within private contractual arrangements (e.g. OECD, 2007; Gassen \& Fülbier, 2015). Nevertheless, organisations with higher need for external financing (e.g. private organisations) will voluntarily disclose more information (Francis et al., 2005), and because lenders of private organisations will likely make use of all publicly available information (e.g. annual reports) (Peek et al., 2010) ${ }^{8}$, annual reporting for larger private organisations with (mandatory and voluntary) audited annual reports may still be regarded as an important communication channel with external stakeholders.

According to agency theory, information asymmetry and conflicting interests between agents and principals generate agency costs. Organisations can reduce these costs by disclosing additional information concerning activities of their management and organisations' economic reality, thus enabling investors and other stakeholders to monitor management more appropriately (OECD, 2007; Álvarez et al., 2008). Voluntary disclosures are in general considered as a response to information asymmetry (Gandía, 2005; Hossain et al., 2005; Boesso \& Kumar, 2007; Orens et al., 2009). In accordance with critical stakeholder theory, Abeysekera (2006, p. 69) argues that "the more powerful the stakeholder, the more likely a firm's managers are to take into account their expectations; hence influencing which information is communicated and how." Considering that lenders are the main source of external financing for private organisations (Koren et al., 2014), they can be labelled as the most important or powerful stakeholder(s) for those. Further, (voluntary) disclosure levels are positively associated with leverage (Hossain et al., 1995; Ahmed \& Courtis, 1999) or with the organisation's need for external financing (Francis et al., 2005). Additionally, in accordance with signalling theory, it is expected that organisations with low(er) leverage ratio and a great need for external (debt) financing are more motivated to send signals to the (financial) market about their financial structure and they will consequently disclose more information voluntarily (Khlifi \& Bouri, 2010). Ahmed and Courtis (1999) argue that organisations, once committed to the issue of debt, are motivated to maintain or reduce their present cost of capital, so they carefully disclose more information (rather than

\footnotetext{
Peek et al. (2010, p. 84) show that creditors "belong among the primary users of general purpose financial statements". Also, Chen et al. (2011) observe the evidence of the importance of the quality of financial reporting in the case of 21 countries. They found that "the quality of financial reporting affects subsequent capital investment efficiency in accordance with theory, even for private firms from emerging markets" (Chen et al., 2011, p. 1269), and that its importance increases in the presence of bank financing. We assume that appropriate public financial (and other) reporting can have positive consequences for private organizations, especially in the case of granting loans.
} 
less) in order to decrease investor (lender) uncertainty about future cash flows and consequently credit risk. According to Sengupta (1998) lenders consider an organization's disclosure policy in their estimate of default risk, which may reduce its cost of debt.

Several factors of external debt financing or of the cost of debt have been studied. Empirical studies analysed, for example, the age of firms (Hyytinen \& Pajarinen, 2007), corporate government practices (Byun, 2007), board quality (Fields et al., 2012), accounting or earnings quality (Francis et al., 2002; Bharath et al., 2008), accounting flexibility (Beatty et al., 2002), audits (Minnis, 2011), auditor choice (Pittman \& Fortin, 2004; Fortin \& Pittman, 2007), audit quality (Karjalainen, 2011) and voluntary audits (Kim et al., 2011; Koren et al., 2014) as such factors. The results did not necessarily show the expected impacts. For example, the cost of debt should be reduced with higher financial reporting transparency (auditing), but the research by Koren et al. (2014) revealed significant positive influence of voluntary audit on interest rate of small private organisations (in Slovenia), which can be attributed to the "labelling effect", i.e. "the creditors see through this label adoption and do not award the firm with lower cost of debt” (Koren et al., 2014, p. 27). Further, a number of studies analysing data support for credit risk assessment have shown a significant communication gap between borrowing organisations and financial institutions as regards key intellectual items of these organisations, the reliance on basic financial indicators only, and an urgent need for the inclusion of more advanced non-financial indicators or intellectual capital into the processes of future assessment of business performance, profitability and cash flows (e.g. Guimón, 2005; Dobija \& Rosolińska, 2010; Sanchez et al., 2013). Orens and Lybaert (2007) show that financial analysts using more forward-looking information as well as information about innovation and research and development make smaller errors in estimating future earnings. The only known exception is the bank practice in Japan, where non-financial information is already included in the credit risk rating process (Yosano \& Koga, 2008) and where also non-listed small and medium-sized organisations are encouraged even at the government level to disclose their intellectual capital for the needs of financial institutions and their loan decisions (Yosano, 2012).

Only two empirical studies focused on intangible assets (Hsuehchang, 2013) and on web-based intellectual capital disclosures (Orens et al., 2009) as factors which might have an impact on or which might be associated with the cost of debt. Both of these studies demonstrated that more intangible assets or more investment into research and development and advertising or better intellectual capital disclosure decrease the cost of debt. Hsuehchang (2013) studied the effect of intangible assets on loan interest rates on a sample of 186
Taiwanese publicly-listed SMEs ${ }^{9}$ with 952 annual observations during the time period 2001-2006 based on financial data collected from the Taiwan Economic Journal database. An important and valuable advantage of this study was the detailed data about $R \& D$ and advertising expenditures (as a measure for intellectual assets), the interest rate data on actual bank loans, the actual risk premiums of loan interest rates (measure for dependent variable) and credit ratings (as important control variable to control for the firm's credit risk). The results have shown that SMEs with greater intellectual assets enjoy lower interest rates on bank loans. In the study by Orens et al. (2009), such detailed (financial) information was not available; therefore, the researchers assessed the level of intellectual capital disclosure and cost of debt on the basis of publicly available information disclosed on corporate web sites in the summer of 2002. For intellectual capital, they self-created a disclosure index, which consists of 42 intellectual capital information items, and the cost of debt capital was measured as the ratio between the interest expenses in 2003 and the sum of the long- and the short-term financial debt at the beginning of 2003. The study was carried out on a sample of 267 largest non-financial listed firms in Belgium, France, Germany, and the Netherlands. One of the reasons for their focus on these continental European countries was the "increasing investor need for voluntary disclosure in order to complement financial statements” (Orens et al., 2009, p. 1537). Their findings show that organisations with greater intellectual capital disclosure benefit from a lower level of information asymmetry, a lower cost of equity capital and a lower cost of debt capital and exhibit a higher firm value. The results of these two studies (Hsuehchang, 2013; Orens et al., 2009) support the existence of the (negative) association between intellectual capital disclosure and the cost of debt capital in the case of listed organisations in emerging and developed capital markets.

In general, bank-based financial systems support relationship lending, which leads to more (financial) information being communicated privately rather than via financial statements (Burgstahler et al., 2006) and annual reports ${ }^{10}$. However, Francis et al. (2005, p. 1128) note that "there are equity markets in countries with more bank-oriented systems, and, therefore, voluntary public disclosure could still be important as means of accessing equity financing as well as creating greater transparency for private debt financing." Hussainey and Aal-Eisa (2009) have shown that the disclosure of forward-looking information in narratives

\footnotetext{
9 According to the author, SMEs are selected because they make great contributions to the economic development in emerging markets.

${ }^{10}$ This is in contrast with market-oriented financial systems, which rely mostly on public equity markets to supply capital financing and therefore demand high-quality financial statements and expended disclosures (Francis et al., 2005; Burgstahler et al., 2006).
} 
of the annual reports is an important mechanism for signalling future earnings to professional users such as financial analysts. As regards intellectual capital, it is considered as a strategic factor/fundamental determinant of (future) value creation in organisations (e.g. MERITUM, 2002; OECD, 1996, 2007). Therefore, it is possible that organisations with information asymmetry problems between management/ owners and lenders, regardless of their size and listing status, voluntarily and publicly disclose (some) intellectual capital information within their annual reports because they expect that this forward-looking information may be important for lenders in evaluating the credibility of the organisations' expected cash flows (Alwert et al., 2009; Minnis, 2011; Bianchi Martini et al., 2016) and rewarding organisations with lower(ing) agency (lending) costs.

The review of the existing research on the association between (and on the impact of) intellectual capital disclosures and (on) different areas of organisation's performance and its valuation were exclusively focused on the samples of listed organisations, which reveals a significant lack of such research as regards private organisations. Actually, compared with the large body of literature on publicly listed organisations, there is a limited extent of research on private (or unlisted) organisations (Chen et al., 2011; Hope, 2015) ${ }^{11}$. Private organisations are often, but not always, less likely to be affected by agency issues between management/owners and lenders than public organisations (Kosi \& Valentincic, 2013) and they are more likely to resolve information asymmetry by an "insider access" model (Ball \& Shivakumar, 2005). In general, lenders are the main source of external financing in private organisations (Koren et al., 2014) although a non-trivial proportion of small private organisations still has no access to external financial debt (Kosi \& Valentincic, 2013); thus, such organisations do not face these agency issues as larger private organisations may. Actually, in large and medium-sized private organisations, which are in Slovenia obligated to the auditing of their annual reports, the agency issues between the managers and/or the owners on the one hand and the lenders on the other have already been studied in the context of cost of debt regarding (voluntary) audits as a possible mitigating factor for these agency issues (Koren et al., 2014) ${ }^{12}$. As regards Slovenian organisations, there is no empirical research of their intellectual capital disclosures and the effects of these disclosures. Only two

\footnotetext{
${ }^{11}$ Hope`s (2015, p. 181) opinion regarding this lack of research is "although some interesting issues by definition can only be examined in public firms, I believe that primary reason for the lack of research on private firms relates to data availability rather than the relative importance of these two types of firms."

${ }^{12}$ Actually, "for private companies, the demand for external audits arises mainly from the need for debt contracting with banks and other private lenders, not from the need for equity financing from arm `s-length investors in the stock market” (Kim et al., 2011, p. 589).
}

studies empirically examined the extent of intellectual capital disclosures of listed Slovenian organisations (Rodman, 2005; Jelenovec, 2015) and only one study focused on Slovenian organisations with audited annual reports (Stropnik \& Korošec, 2016) ${ }^{13}$. Considering the characteristics of private organisations which depend on external financing, possible agency issues between management/owners and lenders for these organisations and the characteristics of poorly developed Slovenian equity market ${ }^{14}$ with predominantly bankbased financial system, we developed the research question whether the level of intellectual capital disclosure (as a whole and of its three individual sub-categories) by private Slovenian organisations with audited annual reports is associated with the cost of their debt capital. To test the stated research question we formulated the following hypotheses:

H1: (Total) intellectual capital disclosure level is negatively associated with the cost of debt capital in Slovenian private audited organisations.

H2: Human capital disclosure level is negatively associated with the cost of debt capital in Slovenian private audited organisations.

H3: Structural capital disclosure level is negatively associated with the cost of debt capital in Slovenian private audited organisations.

H4: Relational capital disclosure level is negatively associated with the cost of debt capital in Slovenian private audited organisations.

\section{Methodology}

\section{Sample}

We tested our hypotheses on the data obtained from publicly available annual reports of 100 Slovenian private organisations, which published their (mandatory or voluntary) audited annual reports for 2014 on the AJPES portal ${ }^{15}$. According to the Slovenian Companies Act (ZGD-1) in force during the

\footnotetext{
${ }^{13}$ Few others studies (Nemec Rudež \& Mihalič, 2007; Jerman et al., 2010; Javornik et al., 2012; Jerman, 2013) investigated intellectual capital (not intellectual capital disclosure) as measured in different ways (e.g. intangibles, recognized in financial accounts; intellectual categories, evaluated using a questionnaire; VAIC) and for different samples of Slovenian organizations (e.g. publicly traded companies; hotel industry; those with at least a minimal presence of elements of intellectual capital).

${ }^{14}$ For example, on 31 December, 2014, there were only 9 organisations listed on prime market of the Ljubljana stock exchange (Ljubljanska borza, 2014).

${ }^{15}$ AJPES (i.e. Agencija Republike Slovenije za javnopravne evidence in storitve) is the Agency of the Republic of Slovenia for Public Legal Records and Related Services.
} 
examined period of time, the annual reports of all large and medium-sized capital companies, dual companies and those small capital companies whose securities are traded on the regulated market had to be audited and submitted to AJPES to be available to general public ${ }^{16}$. After pertinent exclusions were made ${ }^{17}$, our population comprised 1,313 organisations, 60 of which were micro, 119 were small, 639 were medium-sized and 494 were large organisations (for one organisation the size information was missing). The majority of our population (86\%) were thus medium-sized and large organisations ${ }^{18}$ which are obligated to audit their annual reports. We can conclude that the remaining $14 \%$ of organisations in the population decided for the audit of their annual reports voluntarily. In the population, there were (only) 235 private organisations (almost $18 \%$ of the population) with the legal form of a public limited company, i.e. their shares were not traded on a regulated market. Concerning the organisations' main activity ${ }^{19}$, the main proportion of the population (i.e. 464 organisations or 35\%) was engaged in manufacturing, 295 organisations (22\%) in wholesale and retail trade and repair of motor vehicles and motorcycles, and 117 organisations (almost 9\%) were engaged in professional, scientific and technical activities.

Out of this population, 100 organisations were chosen randomly for our sample (every $13^{\text {th }}$ organisation - systematic random sampling) ${ }^{20}$. The sample included 90 (private)

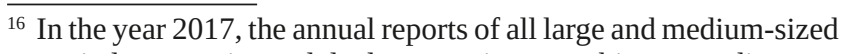
capital companies and dual companies are subject to audit.

${ }^{17}$ According to AJPES, 1,529 audited annual reports of Slovenian organisations for 2014 were publicly available by 7 September 2015. 5 organisations submitted to AJPES a version of their annual report, which means that 1,524 audited annual reports were actually available on the AJPES website by that date. We excluded a number of legal entities from this population due to specifics of our study (banks, insurance companies, co-operatives, economic interest groups), some legal forms of organisations (investment funds, mutual insurance companies, economic interest groups), some activities (financial and insurance activities) and (publicly) listed organisations. The final number of organisations in the population was thus 1,313.

${ }^{18}$ According to the ZGD-1 in force during examined period of time, medium-sized and large organisations by definition fulfil two out of the following conditions in a given financial year: they should employ on average more than 50 employees, should have more than EUR 8.8 million net sales revenue and the value of their total assets should be more than EUR 4.4 million.

19 The classification of activities is based on Slovenian Standard Classification of Activities (SKD 2008) (SURS, 2017).

${ }^{20}$ The sample $(\mathrm{N}=100)$ is not larger due to the complexity of the method used for the analysis of the annual reports' contents. For example, content analysis was used by Li et al. (2008) to study a sample of 100 organisations, by Haji and Ghazali (2012) to study 51 organisations, by Boujelbene and Affes (2013) to study 102 organisations, and Mangena et al. (2016) to study 125 organisations. Although computer search method (i.e. word and phrase count analysis) is used less frequently, it enables the analysis of a significantly larger sample (e.g. Bontis (2003) used this method to analyse annual reports of as many as 11,000 organisations). large and medium-sized organisations. Regarding the legal form of the organisations in the sample, 23 were (private) public limited companies (the rest were limited liability companies). In terms of their main activity, the majority of the organisations were engaged in the following activities: 33 in manufacturing, 23 in wholesale and retail trade and repair of motor vehicles and motorcycles, 10 in construction and 9 in professional, scientific and technical activities. These data show that the structure of the organisations in our sample matches the structure of the population.

\section{Variables}

\section{Intellectual capital disclosures}

To study the scope, the quantity, the levels and the quality of voluntary intellectual capital reporting or its disclosures, the researchers generally use the content analysis method. This is "a method of codifying the text (or content) of a piece of writing into various groups (or categories) depending on selected criteria” (Weber, 1988, in Milne \& Adler, 1999, p. 237) where the content units under analysis can be words, sentences, paragraphs or other items ${ }^{21}$. Our research stemmed from a pre-determined list of individual topics/ characteristics/items of intellectual capital, i.e. a checklist of items, which we searched for in annual reports ${ }^{22}$. A review of checklists used in the existing research revealed that despite the differences in their scope, the most typical items appear more or less in all of them. Usually, the studies apply previously used checklists. However, the research by Li et al. (2008), which was subsequently used in a number of other studies (e.g. Haji \& Ghazali, 2012; Boujelbene \& Affes, 2013; Mangena et al., 2016), provides a concrete analysis of the suitable number of checklist items to be used in a very frequently applied content analysis method. Namely, too few coding categories potentially increase the probability of random agreement in coding decisions and, consequently, overestimate the reliability, whereas a higher number of items increases the complexity and potentially increases the occurrence of coding errors (Milne \& Adler, 1999, Beattie \& Thomson, 2007, in Li et al., 2008, p. 141). Li et al. (2008) thus drafted a pilot research instrument with 150 items, which was then tested and analysed. Based on the results of the test and the discussions with other researchers, they narrowed the research instrument to 61 typical items

${ }^{21}$ The latter were the subject of our codification following a number of existing studies (e.g. Guthrie, 2001; April et al., 2003; Li et al., 2008; Boujelbene \& Affes, 2013).

22 The selected method is very time-consuming and complex because it requires a detailed review of each annual report and a deliberation whether individual items are disclosed or not (the method does not involve word counts, which would be suitable for a fast computer-based measurement of the scope). 
covering all three sub-categories of intellectual capital (22 items for human capital, 18 items for structural capital and 21 items for relational capital). For the purpose of our research, we adapted this checklist by determining an equal number of items for each of the three sub-categories of intellectual capital. Our total number of items was thus 54 (3x18 items). By doing so, we avoided potential preference of any of the three sub-categories of intellectual capital. At the same time, we enabled a mutual comparison of individual intellectual capital sub-categories disclosure levels. Since we were interested in the extent of disclosures and not their quality, we adopted a dichotomous approach in coding. If the item was disclosed, it scored 1 and if it was not disclosed, it scored 0. The presence of each item in the annual report was considered only once (we did not count any repetitions of the same topic and we also gave score 1 to one item only in case of the overlapping contents).

\section{Cost of debt capital}

Interest rates or the costs of loans are defined in loan contracts. However, organisations usually do not disclose them in their annual reports. When only publicly accessible data are available, an estimate for the cost of debt capital as the ratio between all annual interest and other financial expenses and its average annual short-term and long-term financial liabilities towards banks, group organisations and others (the average of the value at the beginning and at the end of the year) was usually used in prior studies (e.g. Pittman
\& Fortin, 2004; Byun, 2007; Hyytinen \& Pajarinen, 2007; Orens et al. 2010; Karjalainen, 2011; Kim et al., 2011; Minnis, 2011). This estimate was used in our research, too.

Variables used in the research are presented in Table 1.

The fundamental assumption of our research is that there is the time lag of the effects of intellectual capital disclosures. That is, we assume that intellectual capital disclosures in the annual report for a given year are not reflected in the reporting year but in the following year. That is why the data for the cost of debt variable are for the year 2014 and the data for disclosure variables are for the year 2013.

\section{Results}

\section{Descriptive statistics}

Descriptive statistics for our sample are given in Table 2.

On average, private organisations in our sample did not disclose intellectual capital in any significant scope as the average level of intellectual capital disclosure as a whole was $23.3 \%$. Out of all three sub-categories of intellectual capital, the highest disclosure level was observed with structural capital (the average of $30.7 \%$ ), which was followed by human capital (the average of 20.8\%), and relational capital (the average of $18.4 \%$ ) as the least disclosed sub-category.

Table 1. Description of variables

\begin{tabular}{|c|c|}
\hline \multicolumn{2}{|c|}{ (disclosure levels) } \\
\hline$I C D$ & $\begin{array}{l}\text { intellectual capital disclosure level in a given year }(t-1) \text {, as the ratio of the number of disclosed items to all intellectual } \\
\text { capital items scored (54); }\end{array}$ \\
\hline$H C D$ & $\begin{array}{l}\text { human capital disclosure level in a given year ( } t-1) \text {, as the ratio of the number of disclosed items to all human capital } \\
\text { items scored (18); }\end{array}$ \\
\hline$S C D$ & $\begin{array}{l}\text { structural capital disclosure level in a given year }(t-1) \text {, as the ratio of the number of disclosed items to all structural } \\
\text { capital items scored (18); }\end{array}$ \\
\hline$C D$ & $\begin{array}{l}\text { relational capital disclosure level in a given year }(t-1) \text {, as the ratio of the number of disclosed items to all relational } \\
\text { capital items scored (18); }\end{array}$ \\
\hline
\end{tabular}

Table 2. Descriptive statistics ( $N=100)$

\begin{tabular}{lcccc} 
& Minimum & Maximum & Mean & Std. Deviation \\
\hline CODC (2014) & 0.0000 & 0.3086 & 0.045377 & 0.0406201 \\
\hline ICD (2013) & 0.0185 & 0.7222 & 0.233144 & 0.1305522 \\
\hline HCD (2013) & 0.0556 & 0.7222 & 0.208335 & 0.1274088 \\
\hline SCD (2013) & 0.0000 & 0.7778 & 0.307226 & 0.1737962 \\
\hline RCD (2013) & 0.0000 & 0.6667 & 0.183898 & 0.1369169 \\
\hline
\end{tabular}


The comparison of the lowest values of the observed levels shows that all private organisations disclosed at least some information about their human capital in their annual reports.

\section{Hypotheses testing results}

First, the correlation analysis between disclosure levels (ICD and HCD, SCD, RCD) was performed. It revealed a very strong positive correlation between the disclosure level of individual sub-categories of intellectual capital and the disclosure level of intellectual capital as a whole (see Table 3), which was expected.

Due to strong (positive) correlations between the intellectual capital disclosure as a whole (ICD) and the disclosures of its sub-categories (HCD, SCD, RCD), we tested our hypotheses, i.e. the association between disclosure levels (ICD, HCD, SCD, RCD) and cost of debt capital (CODC), separately. The correlation analysis did not reveal the existence of statistically significant (negative) correlation (see Table 4). For that reason, we cannot confirm hypotheses H1, $\mathrm{H} 2$, $\mathrm{H} 3$ in $\mathrm{H} 4$.

Following the emphasis made by Koren et al. (2014), who stress the importance of precise measurement of interest rate (cost of debt capital), and warn against drawing conclusions from interest rates based on rough proxies for average interest rates charged by banks and other financial lenders, we also carried out the analysis based on a narrower measurement of the cost of debt capital. That is, we calculated the cost of debt capital as the ratio of annual bank-related interest expenses to average annual short-term and long-term financial liabilities towards banks in the same year (variable CODC_bank). Consequently, the number of observations was reduced to 66 (organisations) because 27 organisations did not have liabilities towards banks and the related financial expenses. Also, detailed data were not available for 7 organisations. Comparison of the results obtained by these two approaches to measuring the cost of debt capital showed a smaller dispersion of variable CODC_bank and the correlation analysis revealed a statistically significant weak positive correlation between the variable CODC_bank and individual disclosure levels (ICD, SCD, RCD) (see Table 5).

Based on these results we, therefore, cannot confirm hypotheses H1, H2, H3 and H4.

\section{Discussion and Conclusion}

As regards the level of intellectual capital disclosures, the results of our research have shown that Slovenian private audited organisations disclose, on average, relatively little information about their intellectual capital or its

Table 3. Correlation coefficients between disclosure levels

\begin{tabular}{llccc} 
& & HCD $(2013)$ & SCD (2013) & RCD (2013) \\
\hline \multirow{3}{*}{ ICD (2013) } & Pearson Correlation & $0.843^{* *}$ & $0.935^{* *}$ & $0.890^{* *}$ \\
\cline { 2 - 5 } & Sig. (2-tailed) & 0.000 & 0.000 & 0.000 \\
\cline { 2 - 5 } & $\mathrm{N}$ & 100 & 100 & 100 \\
\hline
\end{tabular}

${ }^{* *}$ Correlation is significant at the 0.01 level (2-tailed).

Table 4. Correlation coefficient between CODC and disclosure levels

\begin{tabular}{llcccc} 
& & ICD (2013) & HCD (2013) & SCD (2013) & RCD (2013) \\
\hline \multirow{3}{*}{$\operatorname{CODC~(2014)~}$} & Pearson Correlation & 0.084 & 0.046 & 0.053 & 0.131 \\
\cline { 2 - 6 } & Sig.(2-tailed) & 0.404 & 0.647 & 0.600 & 0.194 \\
\cline { 2 - 6 } & $\mathrm{N}$ & 100 & 100 & 100 & 100 \\
\hline
\end{tabular}

Table 5. Correlation coefficient between the variable CODC_bank and disclosure levels

\begin{tabular}{llcccc} 
& & ICD (2013) & HCD (2013) & SCD (2013) & RCD (2013) \\
\hline \multirow{2}{*}{ CODC_bank (2014) } & Pearson Correlation & $0.297^{*}$ & 0.229 & $0.278^{*}$ & $0.289^{*}$ \\
\cline { 2 - 6 } & Sig.(2-tailed) & 0.015 & 0.065 & 6.024 & 0.018 \\
\cline { 2 - 6 } & $\mathrm{N}$ & 66 & 66 & 66 & 66 \\
\hline
\end{tabular}

${ }^{*}$ Correlation is significant at the 0.05 level (2-tailed). 
sub-categories (the average ICD for 2013 was 23.31\%), in their annual reports. The highest disclosure level was determined for structural capital (the average SCD for 2013 was $30.72 \%$ ) and the lowest for relational capital (the average RCD for 2013 was 18.39\%). It is very difficult to compare the values of the quantity of these disclosures with the existing research mainly due to:

(1) various approaches to the application of the content analysis, i.e. the studies may significantly differ from one another in terms of, for example, the use of different checklists of items, the content units and the included assessment of the quality of disclosures;

(2) the organisations in the sample, i.e. the samples usually include listed companies or companies with dispersed ownership which are bound to more extensive disclosures and are thus expected to disclose more information about their intellectual capital, which was empirically confirmed (Williams, 2001; Stropnik \& Korošec, 2016);

(3) the source of information, i.e. the sources are usually publicly available annual reports, while some studies focus in IPO prospectuses (e.g. Bukh et al., 2005; Singh \& Zahn, 2008) or web-based/HTML-type reporting (e.g. Orens et al. 2009, 2010);

(4) capital market or the country in which the study was undertaken; according to Orens et al. (2010, p. 1058) studies usually »ignore how institutional differences may affect content and consequences of Web-based non-financial disclosure practices«, which could be extended to all non-financial disclosures;

(5) the time component; i.e. usually the studies examine the quantity of disclosures in a specific year; also the comparison of the results within a too large time difference makes no sense as the quantity of disclosures should increase over time (Williams, 2001; Haji \& Ghazali, 2012).

Despite all this, we can compare our results about the quantity of disclosures with the results of two studies that are the most similar to our study based on the research methodology applied. The study by Boujelbene and Affes (2013), which was conducted on a sample of 102 companies listed in the French SBF 120 stock market index, showed a very high average intellectual capital disclosure (77.43\%) for the year 2009. The research by Li et al. (2008), which was carried out on the sample of 100 UK listed firms, showed the average intellectual capital disclosure index of $36 \%$ for the year 2004. In our opinion, higher disclosure rates as reported in these two studies are mainly the result of the population selected for the studies (i.e. listed companies) and of a more developed capital market, or even of a different checklist of intellectual capital items. Because we used an adapted checklist of items ${ }^{23}$, the disclosure levels of intellectual capital and its sub-categories were in our case higher; alternatively, they could have been lower if we had used the same checklist. Also, we compared the disclosures within a relatively long time span (years 2004, 2009, and 2013). The comparison with two Slovenian studies (i.e. Rodman, 2005; Jelenovec, 2015) therefore does not make sense due to significant methodological differences ${ }^{24}$.

Regarding the association between the level of intellectual capital disclosure (as a whole and of its three individual sub-categories) of Slovenian private organisations with audited annual reports and their cost of debt capital, the results of our research did not show that the lenders would take into account the level of intellectual capital disclosure as the information about the potential for the future cash flows when deciding on the cost of debt issued to these organisations. This was established with both methods of cost of debt measurement, i.e. the broader one (towards all lenders), where a statistically insignificant correlation between all intellectual capital disclosure levels and cost of debt capital was found, and the narrow one (only towards banks), where an unexpected positive statistically significant correlation between structural, relational and (total) intellectual capital disclosure levels and cost of debt capital (towards banks) was established. Different results obtained when using different cost of debt capital measurement methods highlight the importance of this issue, which was already emphasised by Koren et al. (2014) ${ }^{25}$. As regards our research, the results obtained may be conditioned by different factors or motives which the providers of funds on capital markets and other lenders take into account when deciding on the interest rates on the loans granted. The broader method of cost of debt measurement includes the entire debt financing, i.e. both

\footnotetext{
${ }^{23}$ The basis for content analysis was the checklist of 61 significant items developed by Li et al. (2008) (i.e. 22 items for human capital, 18 items for structural capital and 21 items for relational capital). In order to avoid any potential preference of individual (intellectual capital) sub-category, we set an equal number of items for each (i.e. 18 items). By doing so, we "limited" the basic checklist to 54 items (in the category human capital, we logically merged items "employee commitments", "employee development", "employee capabilities" and "other employee features" with the existing items in this category; in the category relational capital we also logically merged the items "customer retention", "customer involvement" and "market leadership" with other existing items in this category).

${ }^{24}$ For example, Jelenovec (2015) included (only) 23 items in the checklist of intellectual capital and examined the scope of disclosures for 49 listed organisations. On average, these organisations disclosed 8.3 intellectual capital items, which stands for the average of $36 \%$ disclosure rate.

${ }^{25}$ In order to make relevant conclusions, the assessments of the cost of debt capital have to be done with adequate precision. The (average) interest rate at a given point in time is namely the result of (different) loans taken at different lenders in different periods of time.
} 
financing by banks and by issuing bonds, and financing by other organisations in the group or by the natural persons associated with the organisation. Compared with banks, the latter two can, on the one hand, have a better insight into the internal development potential of the related organisations due to their capital/management ties, or may be driven, on the other hand, by other factors when determining the interest rates to the related persons (e.g. tax or private motives) ${ }^{26}$. Although being weak, the positive (statistically significant) correlation between some disclosure levels and the narrow method of the measurement of cost of debt capital (towards banks) as established in our case could be explained by the possibility that the banks do not trust non-financial indicators on intellectual capital with respect to validity and reliability mainly in relation to the credit risk assessment and the assessment of future cash flows. For that reason, the disclosures might be labelled as 'too good to be true' or as 'cheap talk', which is then sanctioned with an even higher cost of debt $^{27}$. Apart from that, the data in this study were measured in the period of an extensive credit crunch when banks were even more sceptical and cautious, and crediting was limited. Additionally, the issue of the measurement of the extent of disclosures arises as these disclosures were measured only quantitatively (i.e. if the individual item was at least mentioned by an organisation), and we did not measure the quality and the value of the additionally disclosed items ${ }^{28}$. According to signalling theory, the information has added/ additional value if it is related to the distinguishing characteristic and if it is disclosed in a quality and user-oriented way (Connelly et al., 2011). In our opinion, reports on intellectual capital are often characterized by a number of similar (e.g. number of employees and education structure) and superficial information which does not have any differential value the assessor would perceive as an advantage or a potential. This could also be the reason why lenders do not consider the level of intellectual capital disclosures when determining the interest rates on loans (i.e. cost of debt) to Slovenian private audited organizations. However, this does not exclude the possibility that the assessors take into account relevant information about the potentials of future cash flows generation as presented in individual items in intellectual capital disclosures. That is, different items of intellectual capital do not have the same significance for the assessment of these potentials (Alwert et al., 2009).

\footnotetext{
${ }^{26}$ The interest rates applied in inter-company loans are usually different than market interest rates (Jost et al., 2011; Schjelderup, 2016).

${ }^{27}$ Similar behaviour of banks when determining interest rates for Slovenian private organisations is deduced by Koren et al. (2014) in relation to voluntary audit; they write about the "labelling” effect, i.e. the situation when banks penalised voluntary audit of small private organisations with higher interest rate.

28 "The quantity of disclosure does not indicate what is actually being disclosed” (Boesso \& Kumar, 2007, p. 276).
}

Our research on the association between the quantity of intellectual capital disclosures and the cost of debt capital is the only empirical one carried out on a sample of Slovenian private audited organisations. Because Slovenian private organisations raise capital predominantly via debt (predominantly via bank loans) and because we can expect the increase in the quantity of intellectual capital disclosures in Slovenia ${ }^{29}$, a number of issues still remain to be researched in the future. Primarily, further studies should be undertaken in relation to the above mentioned methodological upgrade of the research by including the measurement of the quality of intellectual capital disclosures and by observing the association between the cost of debt capital and more disaggregated or individual items in these disclosures. The study of the associations between intellectual capital disclosures and the cost of debt capital in private (audited) organisations in large and more diversified economies from the perspective of different fields of economic activity of these organisations could also be interesting. Due to the small size of Slovenian economy, the impact of the activities the organisations are engaged in was deliberately excluded despite the fact that the organisations which are active in more technology-based or knowledge-intensive industries, show more extensive intellectual capital disclosure(s) (Whiting \& Woodcock, 2011; Boujelbene \& Affes, 2013). Taking this into account, intellectual capital disclosure(s) could have greater significance for the lenders during their assessment of the potentials for future cash flow generation in these organisations. The research into intellectual capital disclosure(s) could also be upgraded with the study of both the motives of those who prepare intellectual capital disclosures in annual reports and the expectations of lenders in relation to these disclosures.

\section{Acknowledgment}

The authors would like to thank the reviewers for their helpful comments.

\footnotetext{
${ }^{29}$ The quantity of intellectual capital disclosures increases over time in some countries (Williams, 2001; Haji \& Ghazali, 2012), so it is reasonable to expect such increase also in Slovenia.
} 
Neca Stropnik, Bojana Korošec, Polona Tominc: The Relationship Between the Intellectual Capital Disclosure and Cost of Debt Capital - A Case of Slovenian Private Audited Organisations

\section{References}

Abdolmohammadi, M. (2005). Intellectual capital disclosure and market capitalization. Journal of Intellectual Capital, 6(3), $397-416$. https://doi.org/10.1108/14691930510611139

Abeysekera, I. (2006). The project of intellectual capital disclosure: researching the research. Journal of Intellectual Capital, 7(1), 61-77. https://doi.org/10.1108/14691930610639778

Ahmed, K., \& Courtis, J. K. (1999).Associations between corporate characteristics and disclosure levels in annual reports: A meta-analysis. British Accounting Review, 31, 35-61. https://doi.org/10.1006/bare.1998.0082

Álvarez, I.G.,Sanchez, I.M.G., \& Dominguez,L.R.(2008).Voluntary and compulsory information disclosed online:The effect of industry concentration and other explanatory factors. Online Information Review, 32(5), 596-622. https://doi.org/10.1108/14684520810913990

Alwert, K., Bornemann, M., \& Will, M. (2009). Does intellectual capital reporting matter to financial analysts? Journal of Intellectual Capital, 10(3), 354-368. https://doi.org/10.1108/14691930910977789

An, Y., Davey, H., \& Eggleton, I. R. C. (2011). Towards a comprehensive theoretical framework for voluntary IC disclosure. Journal of Intellectual Capital, 12(4), 571-585. https://doi.org/10.1108/14691931111181733

April, K., Bosma, P., \& Deglon, D. (2003). IC measurement and reporting: Esteblishing a practice in SA mining. Journal of Intellectual Capital, 4(2), 165-180. https://doi.org/10.1108/14691930310472794

Ball, R., \& Shivakumar, L. (2005). Earnings quality in UK private firms: comparative loss recognition timeliness. Journal of Accounting and Economics, 39(1), 83-128. https://doi.org/10.1016/j.jacceco.2004.04.001

Banka Slovenije. (2014). Poročilo o finančni stabilnosti. Retrieved from https://bankaslovenije.blob.core.windows.net/publication-files/ Financna_stabilnost_SI_WEB.pdf

Beatty, A., Ramesh, K., \& Weber, J. (2002). The importance of accounting changes in debt contracts: The cost of flexibility in covenant calculations. Journal of Accounting and Economics, 33, 205-227. https://doi.org/10.1016/S0165-4101(02)00046-0

Bharath, S. T., Sunder, J., \& Sunder, S. V. (2008). Accounting quality and debt contracting. The Accounting Review, 83(1), 1-28. https://doi. org/10.2308/accr.2008.83.1.1

Bianchi Martini, S., Corvino,A., Doni, F., \& Rigolini,A.(2016). Relational capital disclosure, corporate reporting and company performance: Evidence from Europe. Journal of Intellectual Capital, 17(2), 186-217. https://doi.org/10.1108/JIC-07-2015-0065

Boesso, G., \& Kumar, K. (2007). Drivers of corporate voluntary disclosure: A framework and empirical evidence from Italy and the United States. Accounting, Auditing \& Accountability Journal, 20(2), 269-296. https://doi.org/10.1108/09513570710741028

Bontis, N. (1998). Intellectual capital: an exploratory study that develops measures and models. Management Decision, 36(2), 63-76. https://doi.org/10.1108/00251749810204142

Bontis, N. (2003). Intellectual capital disclosure in Canadian corporations. Journal of Human Resource Costing \& Accounting, 7(1), 9-20. https://doi.org/10.1108/eb029076

Boujelbene, M.A., \& Affes, H. (2013). The impact of intellectual capital disclosure on cost of equity capital:A case of French firms.Journal of Economics Finance and Administrative Science, 18(34), 45 - 53. https://doi.org/10.1016/S2077-1886(13)70022-2

Bozzolan, S., Favotto, F., \& Ricceri, F. (2003). Italian annual intellectual capital disclosure: An empirical analysis. Journal of Intellectual Capital, 4(4), 543-558. https://doi.org/10.1108/14691930310504554

Branswijck, D., \& Everaert, P. (2012). Intellectual capital disclosure commitment: myth or reality? Journal of Intellectual Capital, 13(1), 39-56. https://doi.org/10.1108/14691931211196204

Brüggen, A., Vergauwen, P., \& Dao, M. (2009). Determinants of intellectual capital disclosure: evidence from Australia. Management Decision, 47(2), 233-245. https://doi.org/10.1108/00251740910938894

Bukh, P. N., Nielsen, C., Gormsen, P., \& Mouritsen, J. (2005). Disclosure of information on intellectual capital in Danish IPO prospectuses. Accounting, Auditing \& Accountability Journal, 18(6), 713-732. https://doi.org/10.1108/09513570510627685

Burgstahler, D. C., Hail, L., \& Leuz, C. (2006). The importance of reporting incentives: Earnings management in European private and public firms. The Accounting Review, 81(5), 983-1016. https://doi.org/10.2308/accr.2006.81.5.983

Byun, H. Y. (2007). The cost of debt capital and corporate governance practices. Asia-Pacific Journal of Financial Studies, 36(5), $765-806$.

Cairns, D., Massoudi, D., Taplin, R., \& Tarca, A. (2011). IFRS fair value measurement and accounting policy choice in the United Kingdom and Australia. The British Accounting Review, 43(1), 1-21. https://doi.org/10.1016/j.bar.2010.10.003

Chen, F., Hope, O.-K., Li, Q., \& Wang, X. (2011). Financial reporting quality and investment efficiency of private firms in emerging markets. The Accounting Review, 86(4), 1255-1288. https://doi.org/10.2308/accr-10040

Choong, K. K. (2008). Intellectual capital: definitions, categorization and reporting models. Journal of Intellectual capital, 9(4), 609-638. https://doi.org/10.1108/14691930810913186

Connelly, B. L., Certo, S. T., Ireland, R. D., \& Reutzel, C. R. (2011). Signaling theory: A review and assessment. Journal of Management, 37(1), 39-67. https://doi.org/10.1177/0149206310388419

Cronje, C. J., \& Moolman, S. (2013). Intellectual capital: measurement, recognition and reporting. South African Journal of Economic and Management Sciences, 16(1), 1-12. https://doi.org/10.4102/sajems.v16i1.244

Dobija, D., \& Rosolińska, A. (2010). Intellectual entrepreneurship and credit risk assessment: the Polish experience. Learning and Intellectual Capital, 7(1), 23-39. https://doi.org/10.1504/IJLIC.2010.029532 
Edvinsson, L. (1997). Developing intellectual capital at Skandia. Long Range Planning, 30(3), 366-373. https://doi.org/10.1016/S00246301(97)90248-X

MERITUM, Meritum Project. (2002). Guidelines for managing and reporting on intangibles (intellectual capital report). Retrieved from http:// www.pnbukh.com/files/pdf_filer/MERITUM_Guidelines.pdf

EU. (2014). Direktiva 2014/95/EU evropskega parlamenta in Sveta o spremembi Direktive 2013/34/EU glede razkritja nefinančnih informacij in informacij o raznolikosti nekaterih velikih podjetij in skupin. Retrived from http://eur-lex.europa.eu/legal-content/SL/TXT/?uri=CELEX\%3A32014L0095

Fields, L. P., Fraser, D. R., \& Subrahmanyam, A. (2012). Board quality and the cost of debt capital: The case of bank loans. Journal of Banking \& Finance, 36(5), 1536-1547. https://doi.org/10.1016/j.jbankfin.2011.12.016

Fortin, S., \& Pittman, J. A. (2007). The role of auditor choice in debt pricing in private firms. Contemporary Accounting Research, 24(3), 859-896. https://doi.org/10.1506/car.24.3.8

Francis, J., LaFond, R., Olsson, P., \& Schipper, K. (2002). The market pricing of earnings quality. Retrieved from https://ssrn.com/ abstract $=414140$

Francis, J. R., Khurana, I. K., \& Pereira, R. (2005). Disclosure incentives and effects on cost of capital around the world. The Accounting Review, 80(4), 1125-1162. https://doi.org/10.2308/accr.2005.80.4.1125

Gandía, J. L. (2005). Corporate e-governance disclosure in the digital age: an empirical study of Spanish listed companies. Retrieved from https://ssrn.com/abstract=531182

Gassen, J., \& Fülbier, R. U. (2015). Do creditors prefer smooth earnings? Evidence from European private firms. Journal of International Accounting Research, 14(2), 151-180. https://doi.org/10.2308/jiar-51130

Guimón, J. (2005). Intellectual capital reporting and credit risk analysis. Journal of Intellectual Capital, 6(1), 28-42. https://doi. org/10.1108/14691930510574645

Guthrie, J. (2001). The management, measurement and the reporting of intellectual capital. Journal of Intellectual Capital, 2(1), $27-41$. https://doi.org/10.1108/14691930110380473

Haji, A. A., \& Ghazali, N. A. M. (2012). Intellectual capital disclosure trends: some Malaysian evidence. Journal of Intellectual Capital, 13(3), 377-397. https://doi.org/10.1108/14691931211248927

Haji, A. A., \& Ghazali, N. A. M. (2013). A longitudinal examination of intellectual capital disclosures and corporate governance attributes in Malaysia. Asian Review of Accounting, 21(1), 27-52. https://doi.org/10.1108/13217341311316931

Hidalgo, R. L., Garcia-Meca, E., \& Martinez, I. (2011). Corporate governance and intellectual capital disclosure. Journal of Business Ethics, 100(3), 483-495. https://doi.org/10.1007/s10551-010-0692-x

Hope, O-K. (2015). Discussion of: Do creditors prefer smooth earnings? Evidence from European private firms. Journal of International Accounting Research, 14(2), 181-184. https://doi.org/10.2308/jiar-10471

Hossain, M., Perera, M. H. B., \& Rahman, A. R. (1995). Voluntary disclosure in the annual reports of New Zealand companies. Journal of International Financial Management and Accounting, 6(1), 69-87. https://doi.org/10.1111/j.1467-646X.1995.tb00050.x

Hossain, M., Ahmed, K., \& Godfrey, J. M. (2005). Investment opportunity set and voluntary disclosure of prospective information: A simultaneous equations approach. Journal of Business Finance \& Accounting, 32(5), 871-907. https://doi.org/10.1111/j.0306686X.2005.00616.x

Hsuehchang, T. (2013). The effects of intangible assets on the loan interest rates for small- and medium-sized enetrprises in Taiwan. Journal of Modern Accounting and Auditing, 9(7), 881-888.

Hussainey, K., \& Aal-Eisa, J. (2009). Disclosure and dividend signalling when sustained earnings growth declines. Managerial Auditing Journal, 24(5), 445-454. https://doi.org/10.1108/02686900910956801

Hyytinen, A., \& Pajarinen, M. (2007). Is the cost of debt capital higher for younger firms? Scottish Journal of Political Economy, 54(1), 55-71. https://doi.org/10.1111/j.1467-9485.2007.00404.x

Javornik, S., Tekavčič, M., \& Marc, M. (2012). The efficiency of intellectual capital investments as a potential leading indicator. International Business \& Economics Research Journal, 11(5), 535-558. https://doi.org/10.19030/iber.v11i5.6972

Jelenovec, N. (2015). Dejavniki vpliva na poročanje odprtih slovenskih družb o intelektualnih zmožnostih. Magistrsko delo. Maribor: Ekonomsko-poslovna fakulteta.

Jerman, M., Kavčič, S., \& Kavčič, B. (2010). The significance of intangibles: A comparative analysis between Croatia, Slovenia, Czech Republic, Germany and the USA. Economic Research-Ekonomska Istraživanja, 23(3), 60-69. https://doi.org/10.1080/133167 7X.2010.11517412

Jerman, M. (2013). Intangible assets and their reporting practices: Evidence from Slovenia. Emerald Group Publishing Limited: Accounting in Central and Eastern Europe, (Research in Accounting in Emerging Economies, 13, 187-204. https://doi.org/10.1108/S14793563(2013)0000013013

Joshi, M., Cahill, D., \& Sidhu, J. (2013). Intellectual capital and financial performance: an evaluation of the Australian financial sector. Journal of Intellectual Capital, 14(2), 264-285. https://doi.org/10.1108/14691931311323887

Jost, S. P., Pfaffermayr, M., Stoeckl, M., \& Winner, H. (2011). Profit shifting within multinational firms: The role of entity characterization profiles. Working Paper, February.

Karjalainen, J. (2011). Audit quality and cos tof debt capital for private firms: Evidence from Finland. International Journal of Auditing, 15(1), 88-108. https://doi.org/10.1111/j.1099-1123.2010.00424.x 
Neca Stropnik, Bojana Korošec, Polona Tominc: The Relationship Between the Intellectual Capital Disclosure and Cost of Debt Capital - A Case of Slovenian Private Audited Organisations

Khlifi, F., \& Bouri, A. (2010). Corporate disclosure and firm characteristics: a puzzling relationship. Journal of Accounting- Business \& Management, 17(1), 62-89.

Kim, J. B., Simunic, D. A., Stein, M. T., \& Yi, C. H. (2011). Voluntary audits and the cost of debt capital for privately held firms: Korean evidence. Contemporary Accounting Research, 28(2), 585-615. https://doi.org/10.1111/j.1911-3846.2010.01054.x

Koren, J., Kosi, U., \& Valentincic, A. (2014). Does financial statement audit reduce the cost of debt of private firms? Retrieved from https://ssrn.com/abstract=2373987

Kosi, U., \& Valentincic, A. (2013). Write-offs and profitability in private firms: disentangling the impact of tax-minimisation incentives. European Accounting Review, 22(1), 117-150. https://doi.org/10.1080/09638180.2012.661938

Li, J., Pike, R., \& Haniffa, R. (2008). Intellectual capital disclosure and corporate governance structure in UK firms. Accounting and Business Research, 38(2), 137-159. https://doi.org/10.1080/00014788.2008.9663326

Ljubljanska borza. (2014). Statistike Ljubljanske borze, leto 2014. Retrived from http://www.ljse.si/media/Attachments/Statistika/Podatki/ Letni/Razsirjena_letna_2014_1.pdf

Mangena, M., Pike, R., \& Li, J. (2010). Intellectual capital disclosure practices and effects on the cost of equity capital: UK evidence. London: The Institute of Chartered Accountants of Scotland.

Mangena,M., Li,J., \& Tauringana,V.(2016). Disetangling the effects of corporate disclosure on the cost of equity capital:A study of the role of intellectual capital disclosure. Journal of Accounting, Auditing \& Finance, 31(1), 3-27. https://doi.org/10.1177/0148558X14541443

Milne, M., \& Adler, R. (1999). Exploring the reliability of social and environmental disclosures content analysis. Accounting, Auditing \& Accountability Journal, 12(2), 237-256. https://doi.org/10.1108/09513579910270138

Minnis, M. (2011). The value of financial statement verification in debt financing: Evidence from private U.S. firms. Journal of Accounting Research, 49(2), 457-506. https://doi.org/10.1111/j.1475-679X.2011.00411.x

Nemec Rudež, H., \& Mihalič, T. (2007). Intellectual capital in the hotel industry: A case study from Slovenia. Hospitality Management, 26, 188-199. https://doi.org/10.1016/j.ijhm.2005.11.002

OECD. (1996). The Knowledge-Based Economy. Retrieved from http://www.oecd.org/sti/sci-tech/1913021.pdf

OECD. (2007). Policy Brief: Creating value from intellectual assets. OECD Observer, February 2007, Paris.

Orens, R., \& Lybaert, N. (2007). Does the financial analysts` usage of non-financial information influence the analysts` forecast accuracy? Some evidence from the Belgian sell-side financial analyst. The International Journal of Accounting, 42(3), 237-271. https://doi. org/10.1016/j.intacc.2007.06.002

Orens, R., Aerts, W., \& Lybaert, N. (2009). Intellectual capital disclosure, cost of finance and firm value. Management Decision, 47(10), 1536-1554. https://doi.org/10.1108/00251740911004673

Orens, R., Aerts, W., \& Cormier, D. (2010). Web-based non-financial disclosure and cost of finance.Journal of Business Finance \& Accounting, 37(9-10), 1057-1093. https://doi.org/10.1111/j.1468-5957.2010.02212.x

Peek, E., Cuijpers, R., \& Buijink, W. (2010). Creditors` and shareholders` reporting demands in public versus private firms: Evidence from Europe. Contemporary Accounting Research, 27(1), 49-91. https://doi.org/10.1111/j.1911-3846.2010.01001.x

Pittman, J. A., \& Fortin, S. (2004). Auditor choice and the cost of debt capital for newly public firms. Journal of Accounting and Economics, 37, 113-136. https://doi.org/10.1016/j.jacceco.2003.06.005

Rodman, R. (2005). Načini poročanja o intelektualnem kapitalu podjetja. Magistrsko delo. Ljubljana: Ekonomska fakulteta.

SURS, Statistični urad Republike Slovenije. Standardna klasifikacija dejavnosti (SKD 2008). Retrieved from http://www.stat.si/statweb/ methods/classifications

ZGD-1, Zakon o gospodarskih družbah. (2006). Uradni list RS. Retrieved from http://www.uradni-list.si/1/objava.jsp?urlid=200642\&stevilka=1799

ZTFI,Zakon o trgu finančnih inštrumentov.(2007).Uradni list RS. Retrieved from http://www.uradni-list.si/1/objava.jsp?urlid=200767 \&stevilka=3699

Sanchez, P., Salazar, J. C., \& Basilio, O. (2013). Intellectual capital and productivity: revising policies to support financing innovation in SMEs. 2013 EU-SPRI forum conference, Management of innovation policies.

Schjelderup, G. (2016). The tax sensitivity of debt in multinationals: A review. International Journal of the Economics of Business, 23(1), 109-121. https://doi.org/10.1080/13571516.2015.1115661

Sengupta, P. (1998). Corporate disclosure quality and the cost of debt. The Accounting Review, 73(4), 459-474.

Singh, I., \& Zahn, V. J. (2008). Determinants of intellectual capital disclosure in prospectus of initial public offerings. Accounting and Business Research, 38(5), 409-431. https://doi.org/10.1080/00014788.2008.9665774

Sonnier, B. M., Carson, K. D., \& Carson, P. P. (2009). An examination of the impact of firm size and age on managerial disclosure of intellectual capital by high-tech companies. Journal of Business Strategies, 26(2), 167-190.

Stropnik, N., \& B. Korošec. (2016). Razkritja slovenskih organizacij o intelektualnem kapitalu. Sir*ius, 4(4), 87-105.

Sveiby, K. E. (1997). The new organizational wealth: managing \& measuring knowledge-based assets. San Francisco: Berrett-Koehler Publishers.

Taliyang, S. M., Harun, R. J., Mustafa, N. H., \& Mansor, M. (2014). Intellectual capital disclosure and market capitalization. International Journal of Business and Social Science, 5(10), 96-102.

White, G., Lee, A., \& Tower, G. (2007). Drivers of voluntary intellectual capital disclosure in listed biotechnology companies. Journal of Intellectual Capital, 8(3), 517-537. https://doi.org/10.1108/14691930710774894 
Whiting, R. H., \& Woodcock, J. (2011). Firm characteristics and intellectual capital disclosure by Australian companies. Journal of Human Resource Costing \& Accounting, 15(2), 102-126. https://doi.org/10.1108/14013381111157337

Williams, S. M. (2001). Is intellectual capital performance and disclosure practices related? Journal of Intellectual Capital, 2(3), $192-203$. https://doi.org/10.1108/14691930110399932

Yosano, T., \& Koga, C. (2008). Influence of intellectual capital information on credit risk rating process/criterion and credit conditions-survey analysis of Japanese financial institutions. Kobe University: Graduate School of Business Administration.

Yosano, T. (2012). Reporting on intangibles, a recent servey from Japan. Discussion paper. Kobe University: Graduate School of Business Administration.

Zéghal, D., \& Maaloul, A. (2011). The accounting treatment of intangibles - A critical review of the literature. Accounting Forum, 35(4), 262-274. https://doi.org/10.1016/j.accfor.2011.04.003

\section{Authors}

Neca Stropnik, M.Sc., is an assistant for accounting and auditing at the Faculty of Economics and Business, University of Maribor. She has several years working experience of accounting for small and medium sized enterprises. Her research is currently focused in the field of intellectual capital and its reporting.

Bojana Korošec, Ph.D., is an associate professor for accounting and auditing at the Faculty of Economics and Business, University of Maribor. Her research refers in particular to areas in managerial accounting and financial reporting, valuation of economic categories (including intangibles), social aspects of accounting and behavioral issues in accounting and auditing.

Polona Tominc, Ph.D., is a full-time Professor in the Department of Quantitative Economic Analysis at the Faculty of Economics and Business, University of Maribor. Her research is focused on statistical methods in economics and business sciences, especially in the field of entrepreneurship, gender differences and behavioural differences between social groups in different fields of management.

\section{Povezanost razkritij o intelektualnem kapitalu in cene dolgov - primer slovenskih privatnih revidiranih organizacij}

\section{Izvleček}

Dosedanje empirične raziskave, ki so preverjale povezave med razkritji o intelektualnem kapitalu organizacij in ceno njihovih dolgov, so zelo redke oziroma so izvedene izključno na vzorcu (velikih) organizacij, ki kotirajo na borzi. Ker lahko agencijski problem obstaja med poslovodstvom/lastniki in posojilodajalci tudi v takšnih (večjih) privatnih organizacijah, katerih financiranje je v veliki meri odvisno od posojil in katerih revidirana letna poročila lahko predstavljajo vir dodatnih informacij za zunanje uporabnike, smo s predmetno empirično raziskavo iskali odgovor na vprašanje, ali je stopnja razkritij o intelektualnem kapitalu ter njegovih sestavinah povezana s ceno dolgov, na primeru vzorca privatnih slovenskih organizacij z revidiranimi letnimi poročili. Rezultati raziskave niso pokazali, da bi posojilodajalci pri določanju cene dolgov slovenskim privatnim revidiranim organizacijam upoštevali razkritja o njihovem intelektualnem kapitalu kot informacijo o potencialu za njihove bodoče denarne tokove.

Ključne besede: intelektualni kapital, razkritja o intelektualnem kapitalu, stopnja razkritja intelektualnega kapitala, cena dolgov, privatne organizacije, analiza vsebine 